\title{
Microsatellite variation revealed panmictic pattern for Triatoma brasiliensis (Triatominae: Reduviidae) in rural northeastern Brazil: the control measures implications
}

Claudia Mendonça Bezerra ${ }^{1,2^{*+}}$ (D) Carlota Josefovicz Belisário ${ }^{3+}$, Grasielle Caldas D’Ávilla Pessoa ${ }^{4}$, Aline Cristine Luiz Rosa ${ }^{3}$, Carla Patrícia Barezani ${ }^{3}$, Flávio Campos Ferreira ${ }^{3}$, Alberto Novaes Ramos Jr ${ }^{1}$, Ricardo Esteban Gürtler ${ }^{5,6}$ and Liléia Diotaiuti ${ }^{2}$

\begin{abstract}
Background: Triatoma brasiliensis Neiva, 1911 is the main vector of Trypanosoma cruzi in the caatinga of Northeastern Brazil. Despite of its epidemiological relevance, there are few studies on its genetic variability. Using microsatellite markers, we characterized the variability and dynamics of infestation and reinfestation of $T$. brasiliensis after residual insecticide spraying in five surveys conducted in a well-defined rural area located in the municipality of Tauá, Ceará, between 2009 and 2015. We evaluated: (1) general variability among local of captures; (2) variability along the time analysis (2009, 2010 and 2015); (3) and reinfestation process.

Results: On the analysis (1) global and pairwise $F_{\text {ST }}$ values suggested absence of clusters among the area. AMOVA indicated that total variation is mainly represented by individual differences. Absence of clustering indicates a panmitic unit, with free gene flow. For (2), Pairwise $F_{\text {ST }}$ indicated alterations in the genetic profile of the triatomines along the time. (3) Analysis of the reinfestation process showed that the domiciliary units investigated had different sources of infestation despite of its proximity.
\end{abstract}

Conclusions: Observed homogeneity can be explained by the great dispersal capacity of T. brasiliensis, overlapping the different environments. Persistent house infestation in Tauá may be attributed to the occurrence of postspraying residual foci and the invasion of triatomines from their natural habitats.

Keywords: Chagas disease, Triatoma brasiliensis, Microsatellites, Genetic variability, Ceará state

\footnotetext{
* Correspondence: cmendoncab@gmail.com

†Claudia Mendonça Bezerra and Carlota Josefovicz Belisário contributed equally to this work.

'Departamento de Saúde Comunitária. Rua Professor Costa Mendes 1608 -

Bloco Didático $5^{\circ}$ andar - Rodolfo Teófilo, Universidade Federal do Ceará,

Faculdade de Medicina, Fortaleza, Ceará CEP: 60430-140, Brazil

${ }^{2}$ Secretaria da Saúde do Estado do Ceará, Fortaleza, CE, Brazil

Full list of author information is available at the end of the article
}

(c) The Author(s). 2020 Open Access This article is licensed under a Creative Commons Attribution 4.0 International License, which permits use, sharing, adaptation, distribution and reproduction in any medium or format, as long as you give appropriate credit to the original author(s) and the source, provide a link to the Creative Commons licence, and indicate if changes were made. The images or other third party material in this article are included in the article's Creative Commons licence, unless indicated otherwise in a credit line to the material. If material is not included in the article's Creative Commons licence and your intended use is not permitted by statutory regulation or exceeds the permitted use, you will need to obtain permission directly from the copyright holder. To view a copy of this licence, visit http://creativecommons.org/licenses/by/4.0/. The Creative Commons Public Domain Dedication waiver (http://creativecommons.org/publicdomain/zero/1.0/) applies to the data made available in this article, unless otherwise stated in a credit line to the data. 


\section{Background}

Chagas disease is a chronic infection whose etiological agent is the protozoan Trypanosoma cruzi [1] (Protozoa, Sarcomastigophora, Kinetoplastida, Trypanosomatidae). It is considered a neglected disease by the World Health Organization and its transmission is closely associated with poverty [2, 3]. Currently, it is estimated that 5.7 million people are infected worldwide and other 70 million are at risk of acquiring the infection [2]. In Brazil, it is estimated that in 2015 there was between 1,4-3,4 million cases of $T$. cruzi infection, predominantly chronic cases with a high morbidity/mortality burden [4, 5].

Of the 65 species of triatomines described in Brazil, 28 species (43\%) are found in the Northeastern region, and 20 of them $(71 \%)$ are captured in human sleeping quarters (intradomiciles). The latter indicates these vectors' capacity of frequent domiciliation [6-8]. Currently the Triatoma brasiliensis complex includes two subspecies (Triatoma brasiliensis brasiliensis and Triatoma brasiliensis macromelasoma [9] and six species (Triatoma lenti, Triatoma juazeirensis, Triatoma melanica, Triatoma bahiensis [10], Triatoma sherlocki [11] and Triatoma petrocchiae [8, 12]. T. b. brasiliensis Neiva, 1911, hereby referred as $T$. brasiliensis, is the main vector of T. cruzi in the caatinga region of Northeastern Brazil. It has a wide geographic distribution, high percentages of natural infection, great invasive potential and a prominent role in the domiciliary, peridomiciliary and sylvatic transmission cycles of T. cruzi [13-17]. In sylvatic environments, $T$. brasiliensis is usually found in crystalline rock outcrops, associated especially with rodents, marsupials and bats [18-20]. It is an aggressive and opportunistic species, with very eclectic host-feeding behavior; hence it can colonize several ecotopes in widely diverse environments [18, 21, 22].

Although T. brasiliensis is recognized as an epidemiologically important species, there are few studies on its genetic variability [23-27]. Among the available tools, microsatellite markers are highly useful because of their high genetic polymorphism [28]. Microsatellites or Short Tandem Repeats (STR) are small tandemly repeated DNA sequences (2-6 base pairs) that are widely found in coding and non-coding regions of the genome [29]. STR markers have a codominant inheritance pattern; it is a neutral marker, highly polymorphic and easily PCRamplifiable. They are used to resolve issues of population structure, genetic diversity and conservation in animal populations [30, 31]. For triatomines, microsatellites have provided further insights into the sources of infestation and reinfestation of domiciliary habitats before and after application of residual insecticides [32-36]. In the northern Argentina, this tooll could determine putative sources of reinfestation of the T. infestans and showed that this dispersion is active and female biased.
Here, we characterize the distribution of genetic diversity of $T$. brasiliensis populations using microsatellite markers to: (a) determine the general variability among the samples obtained in 2009 and 2010 by local of capture; (b) observe the temporal variability in insects collected in 2009, 2010 and 2015; (c) investigate the reinfestation process in two domiciliary unities comparing the infestation in 2010 and 2015.

\section{Results}

Six of the nine pairs of tested primers amplified microsatellite loci, but one of them (locus Tb8112) was monomorphic and hence was excluded from the analysis Primers described by Almeida et al. [23] could not amplify them.

\section{General variability}

Differentiation between the 12 sites sampled in 2009 and 2010 accounted for only $0.76 \%$ of the total variability estimated by AMOVA. Among specimens at the same site the proportion was 19.80 and $79.43 \%$ among all sampled specimens. The FST value was $0.01(p=0.98)$, indicating gene flow between $T$. brasiliensis samples in the study area (Table 1 ). The pairwise $F_{\mathrm{ST}}$ values confirm the absence of clusters (Table 2), as found in the analysis of cluster using the software Structure. Mantel test revealed no association between genetic variability of samples and geographical distance. The genotyping result was detailed in Additional file 1.

Based on these results, the sample was treated as a single population and the vector survey periods were taken into consideration to assess infestation dynamics in Tauá.

\section{Variability along the time}

The number of alleles per locus ranged from seven (Tb860) to 25 (Tb124), and the mean number per sample ranged from 10.60 (April 2010) to 13.40 (August 2015) (Table 3; Additional file 2). Observed and expected heterozygosity values are shown in Table 4. All samples showed Hardy-Weinberg disequilibrium as a result of heterozygosity deficit. The same result was found when the loci were evaluated, except for Tb860. The probability of occurrence of null alleles was low in all loci. The lowest frequencies were found in Tb860 and the higher in Tb728.

Most of the variance determined by AMOVA was found between specimens (81.26\%), followed by within-group (18.51\%) and between-group variation, in which variability was only $0.23 \%$. The fixation indices were: $F_{\mathrm{ST}}=0.00 \quad(p=0.64) \quad F_{\mathrm{SC}}=0.19 \quad(\mathrm{p}=0.00)$; and $F_{\mathrm{CT}}=0.19(p=0.00) \quad($ Table 1$)$. The pairwise $F_{\mathrm{ST}}$ 
Table 1 Analysis of molecular variance (AMOVA) for Triatoma brasiliensis using microsatellite of the: (I) samples obtained in 2009 and 2010 according local of capture; (II) insects collected in 2009, 2010 and 2015; (III) reinfestation process in Cachoeira do Júlio locality

\begin{tabular}{|c|c|c|c|c|c|}
\hline & Source of variation & Variance components & Percentage of variation & Fixation Indices & $\mathrm{P}$ \\
\hline \multirow[t]{3}{*}{ I } & Among populations & $0.01(\mathrm{Va})$ & 0.76 & $0.01\left(F_{S T}\right)$ & 0.98 \\
\hline & Among individuals within populations & $0.36(\mathrm{Vb})$ & 19.80 & $0.20\left(F_{\mathrm{SC}}\right)$ & 0.00 \\
\hline & Within individuals & 144.06 (Vc) & 79.43 & $0.21\left(F_{C T}\right)$ & 0.00 \\
\hline \multirow[t]{3}{*}{ II } & Among populations & $0.00(\mathrm{Va})$ & 0.23 & $0.00\left(F_{S T}\right)$ & 0.64 \\
\hline & Among individuals within populations & $0.34(\mathrm{Vb})$ & 18.51 & $0.19\left(F_{S C}\right)$ & 0.00 \\
\hline & Within individuals & 149.23 (Vc) & 81.26 & $0.19\left(F_{C T}\right)$ & 0.00 \\
\hline \multirow[t]{3}{*}{ III } & Among populations & $0.05(\mathrm{Va})$ & 2.41 & $0.02\left(F_{\mathrm{ST}}\right)$ & 0.00 \\
\hline & Among individuals within populations & $0.27(\mathrm{Vb})$ & 14.18 & $0.15\left(F_{\mathrm{SC}}\right)$ & 0.00 \\
\hline & Within individuals & 159.09 (Vc) & 83.41 & $0.17\left(F_{C T}\right)$ & 0.00 \\
\hline
\end{tabular}

ranged from zero to 0.01 . The group of the fourth survey (October 2010) was different from the first one. The 2015 sample was significantly different from that collected in February 2009 and from the two samples of $2010 \quad(p<0.05)$ (Table 4$)$. The largest within-group variability (Fis) was found in 2015 (0.82), and the lowest in October 2010 (0.43). The groups of the first, fourth and fifth surveys had Fis with $p<0.05$, indicating a population structure and deviation from Hardy-Weinberg equilibrium (Table 5).

Table 2 Pairwise $F_{\text {ST }}$ values between the sites with Triatoma brasiliensis captures in Tauá, 2009 and 2010. Diagonally are the $F_{\text {IS }}$ values

\begin{tabular}{|c|c|c|c|c|c|c|c|c|c|c|c|}
\hline Locality & BI & Can & CJ & M & ME & MNP & MNT & MPC & SBI & SC & VT \\
\hline BHA & 0.03 & 0.02 & $0.02^{*}$ & 0.01 & 0.02 & 0.01 & 0.01 & 0.02 & 0.02 & 0.06* & 0.05 \\
\hline BI & & 0.02 & 0.01 & 0.00 & $0.03^{*}$ & 0.01 & 0.00 & 0.01 & 0.01 & 0.01 & 0.03 \\
\hline Can & & & 0.00 & 0.01 & 0.02 & 0.02 & -0.02 & 0.02 & 0.03 & 0.03 & 0.06 \\
\hline CJ & & & & 0.00 & $0.02^{*}$ & 0.01 & 0.00 & $0.01 *$ & 0.01 & 0.03 * & 0.04 \\
\hline $\mathbf{M}$ & & & & & 0.01 & 0.01 & 0.00 & 0.00 & 0.00 & 0.02 & $0.05^{*}$ \\
\hline ME & & & & & & 0.01 & 0.01 & 0.01 & 0.01 & $0.04 *$ & 0.07 \\
\hline MNP & & & & & & & 0.01 & 0.01 & 0.00 & 0.03 & 0.02 \\
\hline MNT & & & & & & & & 0.00 & 0.01 & -0.01 & 0.03 \\
\hline MPC & & & & & & & & & 0.01 & 0.02 & 0.04 \\
\hline SBI & & & & & & & & & & 0.01 & 0.03 \\
\hline SC & & & & & & & & & & & $0.04 *$ \\
\hline
\end{tabular}


Table 3 Number of alleles per locus in Triatoma brasiliensis captured in Tauá

\begin{tabular}{|c|c|c|c|c|c|c|c|c|c|}
\hline \multirow[b]{2}{*}{ Locus } & \multicolumn{5}{|l|}{ Samples } & \multirow[b]{2}{*}{$A v$} & \multirow[b]{2}{*}{ sd } & \multirow[b]{2}{*}{$\mathrm{N}$} & \multirow[b]{2}{*}{$\mathrm{bp}$} \\
\hline & Feb/2009 & Aug/2009 & Apr/2010 & Oct/2010 & Aug/2015 & & & & \\
\hline Tb728 & 8 & 9 & 9 & 9 & 10 & 9.00 & 0.71 & 10 & $300-318$ \\
\hline Tb830 & 12 & 11 & 12 & 10 & 12 & 11.40 & 0.90 & 14 & 274-388 \\
\hline Tb860 & 6 & 6 & 6 & 5 & 6 & 5.80 & 0.45 & 7 & $390-400$ \\
\hline Tb8124 & 21 & 16 & 22 & 14 & 20 & 18.60 & 3.44 & 25 & 214-268 \\
\hline Tb7180 & 15 & 15 & 18 & 15 & 19 & 16.40 & 1.95 & 21 & $218-260$ \\
\hline Mean & 12.40 & 11.40 & 13.40 & 10.60 & 13.40 & 12.24 & 1.24 & 15.40 & \\
\hline s.d. & 5.94 & 4.16 & 6.54 & 4.04 & 5.98 & 5.33 & 1.15 & 7.50 & \\
\hline
\end{tabular}

$A v$ average among loci; $s d$ standard desviation; $N$ number total of alleles per locus; $b p$ base pair size of fragment

Feb/2009: February/2009; Aug/2009: August/2009; Apr/2010: April/2010; Oct/2010: October/2010 and Aug/2015: August/2015

\section{Variability in Reinfestation in Cachoeira do Júlio}

The number of alleles per locus ranged from five (Tb860) to 13 (Tb7180). The group that presented a greater mean number of alleles per locus was the one from the sylvatic environment (6.40) The lowest mean was from domiciliar unit (DU) 13 in 2015 (4.20) (Table 6; Additional file 3).

There were few events of Hardy-Weinberg disequilibrium when observed and expected heterozygosity values were considered (Table 7). The total variability was represented mainly by the diversity among all specimens (83.41\%), followed by within-group variation (14.18\%) and between-group variation (2.41\%). The fixation indixes were: $F_{\mathrm{ST}}=0.02(p=0.82) ; F_{\mathrm{SC}}=0.15(p=0.00)$; and $F_{\mathrm{CT}}=0.17(p=0.00)$ (Table 1$)$. The comparisons of pairwise $F_{\mathrm{ST}}$ showed that the group of DU13 (captured in 2010) differed from that in DU14 (captured in 2015), and also from the sylvatic sample. Bug captures in the two DUs in 2015 suggested no gene flow between them. The only group that presented inbreeding was from the sylvatic environment ( $F$ is with $p<0.05$ ) (Table 8 ). Figure 1 shows the genetic relationship between groups. The reinfestation present in DU13 appears in an independent branch from the others. The most similar groups were the ones from the sylvatic environment and one from DU14, both captured in 2015.

\section{Conclusions}

The studied T. brasiliensis samples constitute a panmitic unit. The persistent infestation of DUs in Tauá may be happening for to two processes: active invasion of triatomines from their natural habitats and restoration of insect populations that survived after residual insecticide spraying, mainly related to operational failures in the process. Such processes explain the current challenges for vector surveillance and control, whose irregularity and limited coverage is a reality.

\section{Discussion}

Microsatellite markers have been helpful for investigating the population dynamics of triatomines with the goal of designing more effective vector control strategies [23, 32, 35, 37-46]. Studies about gene flow can shed light on the process of domiciliation of autochthonous vectors such as $T$. brasiliensis. This species is adapted to human-made artificial ecotopes and the natural environment. Because of this characteristic, it is an epidemiologically important vector in the arid Northeastern region of Brazil [13, 43, 47, 48]. In the caatinga, the livelihoods of inhabitants and livestock production depend on local natural resources. Local inhabitants extract the products they need to survive in the semiarid land. Such process of occupation degrades and transforms the environment,

Table 4 Observed $(\mathrm{Ho})$ and expected $(\mathrm{He})$ heterozygosity, and null allele frequencies estimated per locus (NA) in Triatoma brasiliensis captured in Tauá

\begin{tabular}{|c|c|c|c|c|c|c|c|c|c|c|c|c|c|c|c|}
\hline & \multicolumn{3}{|l|}{ Tb728 } & \multicolumn{3}{|l|}{ Tb830 } & \multicolumn{3}{|c|}{ Tb860 } & \multicolumn{3}{|c|}{ Tb8124 } & \multicolumn{3}{|c|}{ Tb7180 } \\
\hline & $\mathrm{Ho}$ & $\mathrm{He}$ & NA & $\mathrm{Ho}$ & $\mathrm{He}$ & NA & $\mathrm{Ho}$ & $\mathrm{He}$ & NA & $\mathrm{Ho}$ & $\mathrm{He}$ & NA & $\mathrm{Ho}$ & $\mathrm{He}$ & NA \\
\hline February/2009 & $0.52^{*}$ & 0.75 & 0.16 & $0.59 *$ & 0.80 & 0.11 & 0.67 & 0.69 & 0.06 & $0.59^{*}$ & 0.85 & 0.14 & $0.68^{*}$ & 0.85 & 0.09 \\
\hline August/2009 & $0.55^{*}$ & 0.80 & 0.16 & 0.73 & 0.79 & 0.02 & 0.61 & 0.71 & 0.09 & $0.61^{*}$ & 0.83 & 0.11 & 0.72 & 0.87 & 0.08 \\
\hline April/2010 & $0.50^{*}$ & 0.76 & 0.17 & $0.50^{*}$ & 0.74 & 0.13 & 0.63 & 0.68 & 0.06 & $0.53^{*}$ & 0.84 & 0.16 & $0.76^{*}$ & 0.86 & 0.06 \\
\hline October/2010 & $0.58^{*}$ & 0.83 & 0.18 & $0.66^{*}$ & 0.78 & 0.06 & 0.65 & 0.66 & 0.01 & $0.51^{*}$ & 0.86 & 0.18 & $0.68^{*}$ & 0.85 & 0.09 \\
\hline August/2015 & $0.56^{*}$ & 0.76 & 0.14 & $0.70^{*}$ & 0.78 & 0.03 & 0.62 & 0.63 & 0.01 & $0.57^{*}$ & 0.85 & 0.15 & $0.67^{*}$ & 0.85 & 0.10 \\
\hline
\end{tabular}

${ }^{*}$ significant value $(p<0.05)$ 
Table 5 Pairwise $F_{\text {ST }}$ (above diagonal) and $F_{\text {IS }}$ (in diagonal) values genotypic of the Triatoma brasiliensis captured in Tauá from february 2009 to august 2015

Capture date February/2009 August/2009 April/2010 October/2010 August/2015

\begin{tabular}{lccccc}
\hline February/2009 & $\mathbf{0 . 5 5 *}$ & -0.00 & 0.00 & $\mathbf{0 . 0 1} *$ & $\mathbf{0 . 0 0 *}$ \\
August/2009 & & 0.52 & 0.00 & 0.00 & 0.00 \\
April/2010 & & 0.79 & 0.00 & $\mathbf{0 . 0 0}$ \\
October/2010 & & & $\mathbf{0 . 4 8}$ & $\mathbf{0 . 0 0}$ \\
August/2015 & & & & $\mathbf{0 . 8 2 *}$ \\
\hline
\end{tabular}

*significant value $(\mathrm{p}<0.05)$

*significant value $(p<0.05)$

as well as bridges the distance between human beings and various organisms [49], including T. cruzi hosts and vectors $[13,50]$.

The microsatellite loci used in this study were previously used for investigating the molecular ecology of $T$. brasiliensis in Rio Grande do Norte, Northeastern Brazil [23]. These authors described and used other three microsatellite markers and reported gene flow between domestic and sylvatic populations. Our current results for allele size are in agreement with the findings of previous studies $[23,28]$. The locus Tb8112 was also monomorphic for $T$. brasiliensis in Rio Grande do Norte. Although a smaller number of loci was used, the samples from Ceará showed a higher average number of alleles when compared with those from Piauí, Bahia and Rio Grande do Norte [23], probably due to the larger number of individuals sampled.

In the three analyses performed, AMOVA indicated that total variation was mainly represented by individual differences. Variation between groups had a quite low representation, indicating that they were genetically similar, i.e., without population structure. $P$ value of $F_{\mathrm{ST}}$ indicate little genetic variation among samples and corroborate the results mentioned above. This absence of clustering indicates that it is a panmictic unit, with free gene flow. Thus, it was important to verify whether the triatomines found after insecticide spraying also presented the same genetic structure. The large number of alleles with heterozygosis deficit is probably not due to the existence of null alleles, since the latter are not very likely to occur. The Hardy-Weinberg disequilibrium may have been caused by persistent infestation with specimens surviving insecticide spraying as well as the consequent increase of inbreeding. Its occurrence was evidenced by the statistically significant values of Fis relative to groups 2009a, 2010b and 2015.

Although the global $F_{\mathrm{ST}}$ values indicated lack of population structure, the pairwise comparison of this index provided further insights into population dynamics. There was no genotypic differentiation when the first four surveys were compared pairwise $\left(F_{\mathrm{ST}}\right)$, except in the comparison between the first (February 2009) and the last one (October 2010). Such homogeneity can be explained by high gene flow of $T$. brasiliensis in this

Table 6 Number of alleles per locus of Triatoma brasiliensis captured at a domiciliary unit in Cachoeira do Júlio locality

\begin{tabular}{|c|c|c|c|c|c|c|c|c|}
\hline Locus & 2010b_DU13 & 2010b_DU14 & 2015_DU13 & 2015_DU14 & 2015_W & Mean & s.d. & AN \\
\hline Tb728 & 5 & 5 & 4 & 3 & 5 & 4.40 & 0.89 & 7 \\
\hline Tb830 & 6 & 6 & 4 & 6 & 7 & 5.80 & 1.10 & 10 \\
\hline Tb860 & 4 & 4 & 4 & 4 & 3 & 3.80 & 0.45 & 5 \\
\hline Tb8124 & 8 & 8 & 4 & 7 & 7 & 6.80 & 1.64 & 10 \\
\hline Tb7180 & 4 & 6 & 5 & 8 & 10 & 6.60 & 2.41 & 13 \\
\hline Mean & 5.40 & 5.80 & 4.20 & 5.60 & 6.40 & 5.48 & 0.81 & 9.00 \\
\hline s.d. & 1.67 & 1.48 & 0.45 & 2.07 & 2.61 & 1.66 & 0.80 & 3.08 \\
\hline
\end{tabular}

$2010 b$ October/2010; 2015: August/2015; DU13 domiciliar unit 13; DU14 domiciliar unit 14, W wild; s.d. standard deviations; $A N$ total number of allele 
Table 7 Observed (Ho) and expected (He) heterozygosity per locus of Triatoma brasiliensis captured in Cachoeira do Júlio locality

\begin{tabular}{|c|c|c|c|c|c|c|c|c|c|c|}
\hline \multirow{2}{*}{$\begin{array}{l}\text { locus } \\
\text { Sample }\end{array}$} & \multicolumn{2}{|l|}{ Tb728 } & \multicolumn{2}{|c|}{ Tb830 } & \multicolumn{2}{|l|}{ Tb860 } & \multicolumn{2}{|c|}{ Tb8124 } & \multicolumn{2}{|c|}{ Tb7180 } \\
\hline & $\mathrm{Ho}$ & $\mathrm{He}$ & $\mathrm{Ho}$ & $\mathrm{He}$ & $\mathrm{Ho}$ & $\mathrm{He}$ & $\mathrm{Ho}$ & $\mathrm{He}$ & $\mathrm{Ho}$ & $\mathrm{He}$ \\
\hline DU13_2010 & 0.75 & 0.78 & 0.75 & 0.72 & 0.38 & 0.62 & $0.63^{*}$ & 0.91 & 0.75 & 0.72 \\
\hline DU14_2010 & 0.63 & 0.83 & 0.88 & 0.81 & $0.75^{*}$ & 0.76 & 0.75 & 0.88 & 0.63 & 0.77 \\
\hline DU13_2015 & $0.25^{*}$ & 0.82 & 0.60 & 0.73 & 1.00 & 0.80 & $0.40^{*}$ & 0.64 & 1.00 & 0.84 \\
\hline DU14_2015 & 0.38 & 0.51 & 0.75 & 0.78 & 0.88 & 0.74 & 0.63 & 0.87 & 0.75 & 0.90 \\
\hline W_2015 & 0.67 & 0.69 & 0.60 & 0.74 & 0.53 & 0.57 & $0.20^{*}$ & 0.72 & 0.80 & 0.74 \\
\hline
\end{tabular}

DU13 domiciliar unit 13; DU14 domiciliar unit 14, W wild; 2010: October/2010; 2015: August/2015; *significant value ( $p<0.05)$

region, well-known for its great capacity of dispersal and colonization of domiciliary ecotopes [21, 37-40]. The difference between triatomines caught in the first and last surveys would reflect the elimination of preexisting triatomines following three insecticide applications (2009b, 2010a, 2010b) and the invasion of new specimens of $T$. brasiliensis into DUs over the 20-month period between these two surveys.

The dendrogram representing pairwise $F_{\mathrm{ST}}$ of Cachoeira do Júlio samples makes it clear that microsatellites are highly sensitive markers for detailed analysis of population dynamics. Although geographically close $(45 \mathrm{~m})$ and interconnected by various peridomestic structures, the two DUs had different sources of infestation. DU 13 was probably reinfested after October 2010, given the clear separation of its two groups. The two catches at DU 14 were strongly associated with wild sample, especially the second one, although they were approximately $1300 \mathrm{~m}$ away. It may be concluded that this DU had a persistent infestation caused by residual foci and the continuous invasions of wild triatomines. This analysis also showed that Fis was significant $(p \leq 0.05)$ in the wild sample. This fact suggests no flow of specimens from artificial to natural habitats.
Studies about gene flow can shed light on the process of domiciliation of autochthonous vectors such as $T$. brasiliensis. This species is adapted to human-made artificial ecotopes and the natural environment. Because of this characteristic, it is an epidemiologically important vector in the arid Northeastern region of Brazil [13, 38, $41,42]$. In the Caatinga biome, the livelihoods of inhabitants and livestock production depend on local natural resources. Local inhabitants extract the products they need to survive in the semiarid land. Such process of occupation degrades and transforms the environment, as well as bridges the distance between human beings and various organisms [43], including T. cruzi hosts and vectors $[13,44]$.

Microsatellite markers have been helpful for investigating the population dynamics of triatomines with the goal of designing more effective vector control strategies $[23,32,35,37,41,45-52]$. Thus, the elimination of residual triatomine outbreaks after home spraying can be achieved if operational failures are identified and resolved, for example, through the correct application of insecticide, periodic coverage, supervision, monitoring and regular assessments of entomological and epidemiological indicators of worked areas. As for the prevention and early detection of invasions of wild insects, as it

Table 8 Genotypic differentiation among samples (pairwise $F_{S T}$ ) and intra sample $\left(F_{I S}\right)$ in diagonal from Cachoeira do Júlio locality

Sample DU13_2010 DU14_2010 DU13_2015 DU14_2015 W_2015

\begin{tabular}{l|ccccc}
\hline DU13_2010 & 0.14 & 0.02 & $\mathbf{0 . 0 9 *}$ & 0.03 & $\mathbf{0 . 0 6}^{*}$ \\
DU14_2010 & & 0.11 & 0.01 & 0.03 & 0.02 \\
DU13_2015 & & & 0.11 & $\mathbf{0 . 0 6 *}$ & 0.05 \\
DU14_2015 & & & 0.12 & 0.01 \\
W_2015 & & & & & $\mathbf{0 . 2 0 *}$
\end{tabular}




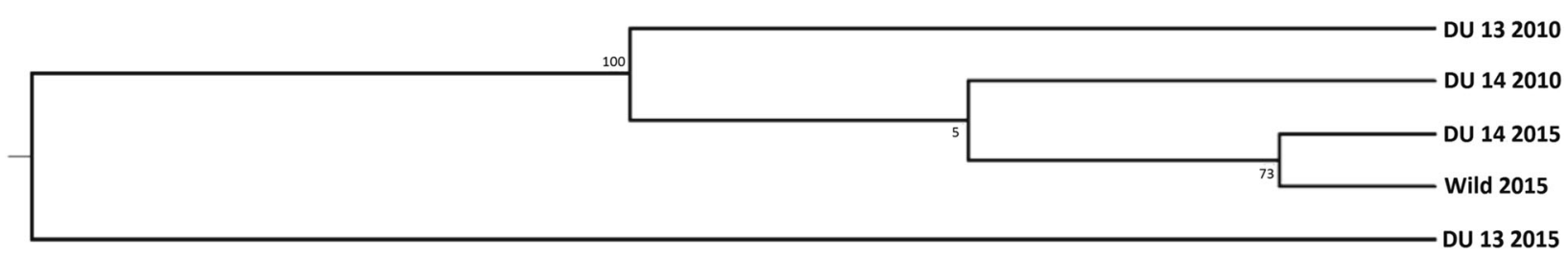

Fig. 1 UPGMA dendrogram of the pairwise FST of Triatoma brasiliensis. Captured in domiciliary units (C13 and C14) and wild environment (S) of Cachoeira do Júlio (CJ) locality. Captured in 2010 and 2015. The numbers in the branch are the bootstrap

depends on the participation of residents, the intervention methodologies must be adequate considering the social, economic, ecological context and through an intersectoral approach that seeks sustainable, participatory and able to timely identify the risk of $T$. cruzi vector transmission infection in the human population $[53,54]$.

\section{Methods}

\section{Research design and study site}

This is a longitudinal study conducted in the municipality of Tauá, in the arid Northeastern region of Brazil, in Ceará state (CE) (Fig. 2). Tauá is located in the Sertão dos Inhamuns $\left(6^{\circ} 00^{\prime} 11^{\prime \prime} \mathrm{S}\right.$; 40 $0^{\circ} 17^{\prime} 34^{\prime \prime}$

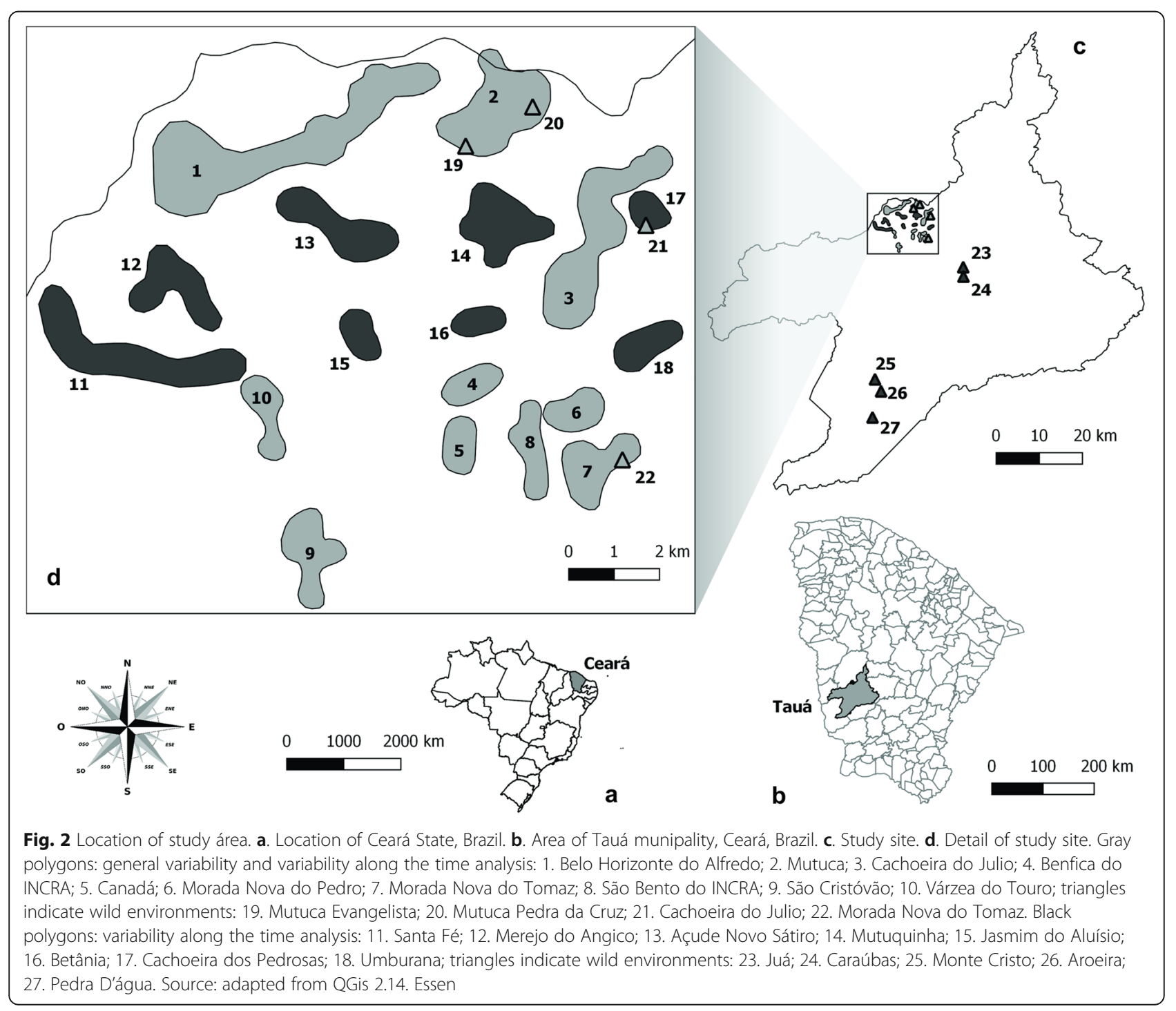


W), $310 \mathrm{~km}$ from Fortaleza, at an altitude of $402.7 \mathrm{~m}$. Average temperature ranges between $26^{\circ} \mathrm{C}$ and $28^{\circ} \mathrm{C}$ and average annual rainfall is $597.2 \mathrm{~mm}^{3}$, occurring from February to April [55]. Tauá is located in an area with deserts and xeric shrublands, where most trees and shrubs are thorny, dense, small and twisted, have small xeric leaves and well-developed roots. This vegetation is indicative of the most typical local climate. The presence of shallow, stony and dry soils during most of the year is a predominant characteristic [54, 56, 57]. Small mammals, reptiles and insects live in this habitat, including T. brasiliensis, whose natural biome is the Caatinga [58].

The Domiciliar Unit (DU) consists of human habitations (intradomicile) and its surroundings (peridomicile), including all permanent and temporary buildings, fences, piled materials, animal shelters, and so on [59]. The last residual insecticide spraying campaign against triatomines had occurred 2 years prior to the beginning of the present study. The DUs were inspected for infestation in five occasions: February 2009 (before first spraying), August 2009 (6 months after first spraying), April 2010 (14 months after first spraying), October 2010 (20 months after first spraying) and August 2015 (78 months after first spraying). Trained municipal health agents performed manual triatomines searches inside (intradomiciliar, minimum $30^{\prime}$ ) and around (peridomicile, minimum 30') the house. All sighted triatomines were captured as much as possible, according to standard procedures [59]. A team from the State Department of Health supervised field activities was. All DUs (positive and negative) were sprayed with 20\% SC alpha-cypermethrin (Fersol Industry and Trade) in Februay 2009, according to routine procedures of Chagas disease control program. In subsequent surveys only households with a current triatomine infestation were selectively sprayed with insecticide using the same procedures [60].

Sylvatic triatomines were searched at nine sites which had rocky outcrops, a typical natural ecotope of T. brasiliensis. Three of these sites were sampled in the five above-mentioned occasions; other six were included only in 2015 (Fig. 2, Table 9).

It was captured 3005 triatomines, being $64.2 \%$ in the artificial environment and $38.2 \%$ in the wild. For this study, we used samples with a minimum of five insects/ group, as required for the molecular variance analysis (AMOVA) [61, 62].

Table 9 (stay here).

\section{Microsatellites analysis General variability}

For this analysis, 329 triatomines were used. The insects were captured on the four occasions in 2009 and 2010:
147 captured in 47 DUs e 182 in three rocky outcrops (Fig. 2; Table 3). The insects were obtained in 12 local of capture (10 only in artificial ecotopes, two in wild ecotopes and one in both environments) (Table 10). The insects were grouped according to the capture location regardless of their ecotope so that the largest number of locations could be represented due to the minimum sample size.

\section{Variability along the time}

Triatomines from 25 locals of capture were clustered according to the five periods sampled, regardless of location and ecotope, in a total of 722 insects (Table 9).

\section{Variability in Reinfestation in Cachoeira do Júlio}

The peridomicile reinfestation of two DUs (13 and 14) in the locality of Cachoeira do Júlio was investigated in greater detail. For this analysis, the triatomines were grouped by DU and date of capture: (I) eight triatomines captured on October 2010 in DU 13; (II) five on August 2015 in DU 13; (III) eight on October 2010 in DU 14; (IV) eight on August 2015 on DU 14; and (V) 15 on August 2015 in the sylvatic environment.

\section{Microsatellites genotyping}

Genomic DNA was extracted from two legs of each specimen with the Wizard ${ }^{\oplus}$ Genomic DNA Purification Kit (Promega) following the manufacturer's recommendations. DNA was quantified individually in a NanoDrop 1000 Spectrophotometer (Thermo Scientific) and stored at $-20^{\circ} \mathrm{C}$.

Primers were tested for nine microsatellite loci previously described for T. brasiliensis: Tb728, Tb830, Tb860, Tb7180, Tb8112, Tb8124 (13), Tb2146, Tb8102 and Tb8150 (11). Polymerase Chain Reactions (PCR) were run in a final volume of $10 \mu \mathrm{L}$ containing 1 unit of Platinum ${ }^{\circ}$ Taq DNA polymerase (Invitrogen), $1 \mathrm{x}$ buffer, $1.5 \mathrm{mM} \mathrm{MgCl} 2,1 \mathrm{mM} \mathrm{dNTP}$, 5 pmol for each primer, 2 ng DNA and ultrapure water. The forward primers were labeled with a bioluminescent probe. The reactions were run in a Veriti ${ }^{\circ}$ 96-Well thermocycler (Thermo Fisher Scientific) with the following cycle: initial denaturation at $95^{\circ} \mathrm{C}$ for $5 \mathrm{~min}, 28$ cycles at $94^{\circ} \mathrm{C}$ for 30 s, annealing at primer-dependent temperature for $30 \mathrm{~s}$, extension at $72{ }^{\circ} \mathrm{C}$ for $45 \mathrm{~s}$, followed by a final extension at $72{ }^{\circ} \mathrm{C}$ for $5 \mathrm{~min}$. Annealing temperatures were $48^{\circ} \mathrm{C}$ for $\mathrm{Tb} 860 ; 54{ }^{\circ} \mathrm{C}$ for $\mathrm{Tb} 8112 ; 52{ }^{\circ} \mathrm{C}$ for $\mathrm{Tb} 2146$; $56^{\circ} \mathrm{C}$ for Tb8102; touchdown (reduction of incremental annealing temperature): $60 \rightarrow 50^{\circ} \mathrm{C}$ and $58^{\circ} \mathrm{C}$ for Tb728, Tb830, Tb7180, Tb8124. 
Table 9 Triatomines captured in the municipality of Tauá to evaluate the variability along the studied period

\begin{tabular}{|c|c|c|c|c|c|c|c|c|c|c|c|c|c|c|c|c|c|c|c|c|c|c|c|}
\hline \multirow{2}{*}{$\begin{array}{l}\text { Period } \\
\mathrm{CL}\end{array}$} & \multicolumn{4}{|c|}{ February 2009} & \multicolumn{4}{|c|}{ August 2009} & \multicolumn{4}{|c|}{ April 2010} & \multicolumn{4}{|c|}{ October 2010} & \multicolumn{4}{|c|}{ August 2015} & \multicolumn{3}{|c|}{ Total sample } \\
\hline & DU & $A E$ & WE & $\pi$ & $\mathrm{DU}$ & $\mathrm{AE}$ & WE & $\pi$ & $\mathrm{DU}$ & $A E$ & WE & $\pi$ & $\mathrm{DU}$ & $A E$ & WE & $\pi$ & $\mathrm{DU}$ & $A E$ & WE & $\pi$ & $\overline{A E}$ & WE & insects \\
\hline ANS & & & & & & & & & & & & & & & & & 1 & 15 & & 15 & 15 & 0 & 15 \\
\hline ARO & & & & & & & & & & & & & & & & & & & 11 & 11 & 0 & 11 & 11 \\
\hline Bet & & & & & & & & & & & & & & & & & 1 & 1 & & 1 & 1 & 0 & 1 \\
\hline BHA & 1 & 2 & & 2 & 1 & 1 & & 1 & 1 & 2 & & 2 & 5 & 11 & & 11 & 1 & 4 & & 4 & 20 & 11 & 31 \\
\hline BI & & & & & 1 & 1 & & 1 & 2 & 6 & & 6 & 2 & 9 & & 9 & 1 & 3 & & 3 & 19 & 9 & 28 \\
\hline Can & 1 & 1 & & 1 & & & & & 2 & 4 & & 4 & 1 & 5 & & 5 & 2 & 2 & & 2 & 12 & 5 & 17 \\
\hline CB & & & & & & & & & & & & & & & & & & & 12 & 12 & 0 & 12 & 12 \\
\hline CJ & 2 & 3 & 17 & 20 & 5 & 13 & 16 & 29 & 1 & 1 & 29 & 30 & 5 & 22 & & 22 & 7 & 31 & 15 & 46 & 70 & 99 & 169 \\
\hline $\mathrm{CP}$ & & & & & & & & & 1 & 2 & & 2 & & & & & 2 & 4 & & 4 & 6 & 0 & 6 \\
\hline JA & & & & & & & & & 1 & 2 & & 2 & 1 & 1 & & 1 & 2 & 4 & & 4 & 7 & 1 & 8 \\
\hline JUA & & & & & & & & & & & & & & & & & & & 14 & 14 & 0 & 14 & 14 \\
\hline$M$ & 3 & 6 & & 6 & & & & & 6 & 12 & & 12 & 5 & 18 & & 18 & 10 & 64 & & 64 & 100 & 18 & 118 \\
\hline MA & 1 & 2 & & 2 & & & & & & & & & & & & & 3 & 20 & & 20 & 22 & 0 & 22 \\
\hline MC & & & & & & & & & & & & & & & & & & & 12 & 12 & 0 & 12 & 12 \\
\hline ME & & & 8 & 8 & & & 1 & 1 & & & 12 & 12 & & & & & & & 14 & 14 & 0 & 35 & 35 \\
\hline Mnha & & 1 & & 1 & & 1 & & 1 & & & & & & & & & 3 & 11 & & 11 & 13 & 0 & 13 \\
\hline MNP & 5 & 14 & & 14 & 2 & 2 & & 2 & 3 & 3 & & 3 & 2 & 4 & & 4 & 4 & 7 & & 7 & 30 & 4 & 34 \\
\hline MNT & 2 & 2 & & 2 & 2 & 2 & & 2 & 4 & 5 & & 5 & 2 & 3 & & 3 & 10 & 15 & 11 & 26 & 27 & 14 & 41 \\
\hline MPC & & & 32 & 32 & & & 15 & 15 & & & 13 & 13 & & & & & & & 7 & 7 & 0 & 67 & 67 \\
\hline PA & & & & & & & & & & & & & & & & & & & 15 & 15 & 0 & 15 & 15 \\
\hline SBI & 1 & 5 & & 5 & & & & & 2 & 2 & & 2 & 2 & 2 & & 2 & 2 & 2 & & 2 & 11 & 2 & 13 \\
\hline SC & & & & & 1 & 1 & & 1 & 2 & 7 & & 7 & & & & & 3 & 13 & & 13 & 21 & 0 & 21 \\
\hline SF & & & & & & & & & 1 & 1 & & 1 & & & & & 2 & 5 & & 5 & 6 & 0 & 6 \\
\hline Um & & & & & & & & & 1 & 2 & & 2 & & & & & 1 & 1 & & 1 & 3 & 0 & 3 \\
\hline VT & 1 & 5 & & 5 & & & & & & & & & & & & & 1 & 5 & & 5 & 10 & 0 & 10 \\
\hline Total & 17 & 41 & 57 & 98 & 12 & 21 & 32 & 53 & 27 & 49 & 54 & 103 & 25 & 75 & & 75 & 56 & 207 & 111 & 318 & 393 & 329 & 722 \\
\hline
\end{tabular}

$C L$ local of capture; $D U$ Domiciliary units investigated; $E A$ triatomines captured in artificial environments; $W E$ triatomines captured in wild environments; $\Pi T$ total of triatomine; ANS Açude Novo do Sátiro; ARO Aroeira Bet Betânia; BHA Belo Horizonte do Alfredo; BI Benfinca do Incra; Can Canadá; CB:Caraúbas; CJ Cachoeira do Júlio; CP Cachoeira dos Pedrosas; JA Jasmim Aluizio; JUA Juá; M Mutuca; MA Merejo do Angico; MC Monte Cristo; ME Mutuca Evangelista; Mnha Mutuquinha; MNP Morada Nova do Pedro; MNT Morada Nova do Thomaz; MPC Mutuca Pedra da Cruz; PA Pedra D'Água; SBI São Bento do Incra; SC São Cristovão; SF Santa Fé; Um Umburana; VT Várzea do Touro

To determine locus size, the PCR products were diluted 1:10 in ultrapure water with a GeneScan ${ }^{\text {TM }} 500$ LIZ $^{\circ}$ dye size standard (Thermo Fisher Scientific) and genotyped in an ABI 3730 DNA Analyzer (Applied Biosystem $^{\circ}$ ) by the DNA Sequencing Platform of René Rachou Institute. Chromatogram analysis was performed with the software Geneious 10.1.2@ (Biomatters Limited).

\section{Data Analysis}

The number and size of alleles for each locus, observed (Ho) and expected heterozygosity ( $\mathrm{He}$ ) and Hardy-Weinberg equilibrium (HW) were determined using Arlequin version 3.1 [61, 62]. The occurrence of null alleles was checked with the software Micro-Checker 2.2.3; these frequencies were calculated for each locus by population with GENEPOP $[63,64]$. Cluster presence was assessed by STRUCTURE [65].

AMOVA was used to determine the variance components and proportions of global, interpopulation and intrapopulation variability within total variation. In addition, the following fixation indices were estimated: $F_{\mathrm{ST}}$ (among populations), $F_{\mathrm{SC}}$ (among individuals within populations) and $F_{\mathrm{CT}}$ (within individuals). We evaluated the genotypic diversity between each sample pair (pairwise $\left.F_{\mathrm{ST}}\right)$ and intrapopulation $\left(F_{\mathrm{IS}}\right)$. The tests were run with a $5 \%$ significance level and a maximum loss of $5 \%$ 
Table 10 Triatoma brasiliensis captured in the municipality of Tauá for the general variability study

\begin{tabular}{|c|c|c|c|c|c|c|c|c|c|c|c|c|c|c|c|c|}
\hline \multirow{2}{*}{$\begin{array}{l}\text { Period } \\
\mathrm{CL}\end{array}$} & \multicolumn{3}{|c|}{ February 2009} & \multicolumn{3}{|c|}{ August 2009} & \multicolumn{3}{|c|}{ April 2010} & \multicolumn{3}{|c|}{ October 2010} & \multicolumn{4}{|c|}{ Total sample } \\
\hline & DU & $\mathrm{AE}$ & WE & DU & $\mathrm{AE}$ & WE & DU & $A E$ & WE & DU & $A E$ & WE & DU & $A E$ & WE & Total \\
\hline $\mathrm{BHA}$ & 1 & 2 & & 1 & 2 & & 1 & 2 & & 5 & 11 & & 6 & & 17 & 17 \\
\hline BI & & & & 1 & 1 & & 2 & 6 & & 2 & 9 & & 2 & & 16 & 16 \\
\hline Can & 1 & 1 & & & & & 2 & 4 & & 1 & 5 & & 2 & & 10 & 10 \\
\hline CJ & 2 & 3 & 18 & 5 & 13 & 16 & 1 & 1 & 29 & 5 & 23 & & 6 & 63 & 40 & 103 \\
\hline$M$ & 3 & 6 & & & & & 6 & 12 & & 5 & 19 & & 11 & & 37 & 37 \\
\hline ME & & & 10 & & & 1 & & & 12 & & & & & 23 & 0 & 23 \\
\hline MNP & 5 & 14 & & 2 & 2 & & 3 & 3 & & 2 & 5 & & 7 & & 24 & 24 \\
\hline MNT & 2 & 2 & & 2 & 2 & & 4 & 5 & & 2 & 3 & & 10 & & 12 & 12 \\
\hline MPC & & & 32 & & & 16 & & & 13 & & & & & 61 & 0 & 61 \\
\hline SBI & 1 & 10 & & & & & & & & 2 & 2 & & 3 & & 12 & 12 \\
\hline SC & & & & 2 & 2 & & 2 & 7 & & & & & & & 9 & 9 \\
\hline VT & 1 & 5 & & & & & & & & & & & & & 5 & 5 \\
\hline Total & 16 & 43 & 60 & 13 & 22 & 33 & 21 & 40 & 54 & 24 & 77 & 0 & 47 & 147 & 182 & 329 \\
\hline
\end{tabular}

DU Domiciliar units investigated; $E A$ triatomines captured in artificial environments; WE triatomines captured in wild environments; $C L$ local of capture; $B H A$ Belo Horizonte do Alfredo; BI Benfica do Incra; Can Canadá; CJ Cachoeira do Júlio; M Mutuca; ME Mutuca Evangelista; MNP Morada Nova do Pedro; MNT Morada Nova do Thomaz; MPC Mutuca Pedra da Cruz; SBI São Bento do Incra; SC São Cristóvão; VT Várzea do Touro

of amplified alleles. The Mantel test was also carry out in the cluster research. All these analyses were performed with Arlequin version 3.1 [61, 62]. To evaluated the reinfestation of Cachoeira do Júlio, a UPGMA tree also was built, based on genetic distance (pairwise $F_{\mathrm{ST}}$ ) (POPTREEW) [66].

\section{Supplementary information}

Supplementary information accompanies this paper at https://doi.org/10. 1186/s12863-020-00903-w.

\section{Additional file 1. \\ Additional file 2. \\ Additional file 3 .}

\section{Abbreviations}

DU: Domiciliar unit; $F_{15}$ : Inbreeding coefficient of an individual (I) relative to the subpopulation (S); $F_{1 T}$ : Inbreeding coefficient of an individual (I) relative to the total (T) population; FST: Inbreeding coefficient of subpopulations (S) compared to the total population (T); HE: Heterozygosity Expected;

HO: Heterozygosity Observed; HW: Hardy-Weinberg equilibrium;

PCR: Polymerase Chain Reactions; STR: Short Tandem Repeats;

UPGMA: Unweighted Pair Group Method With Arithmetic Mean

\section{Acknowledgments}

To the 14a Regional Health Office, municipality of Tauá (CE), particularly Maria Dulce Feitosa (Coordinator) and José Silvério do Nascimento Júnior; to the Vector Control Center of the Health Department of the State of Ceará; to the DNA Sequencing Platform at IRR/Fiocruz Minas.

\section{Authors' contributions}

All authors substantially contributed to the development of the study. CMB, $C J B, G C D P, R E G, A N R J$ and $L D$ were in charge of the experimental design and data analysis. CMB and $L D$ collected the insects. CMB, CJB, GCDP, ACLR, CPB and FCF conducted the experiments. CJB and CMB drafted the basic text of the manuscript, with contributions from the other authors. All authors read and approved the final manuscript.

\section{Funding}

WHO / TDR Project A70596, National Council for Scientific and Technological Development (CNPq), René Rachou Institute, Oswaldo Cruz Foundation (Fiocruz-Minas), Foundation for Research Support of Minas Gerais State (FAPE $\mathrm{MIG})$, Coordination of Superior Level Staff Improvement (CAPES) ID 23038.001614/2016-52, Department of Health of Ceará State (SESA-CE). The funding bodies played no role in the design of the study and collection, analysis, and interpretation of data and in writing the manuscript.

\section{Availability of data and materials}

The data generated or analyzed in this study are included in this article and its additional files.

Ethics approval and consent to participate

Approved by the Chico Mendes Institute for Biodiversity Conservation of the Ministry of the Environment (ICMBio/ME), through the Biodiversity Authorization and Information System (BAIS), process \# 31,693-1 and authentication code 46619742 . The project was submitted to the Animal Ethical Committee of the Federal University of Ceará (protocol 103, October 2011). No human participants were used.

\section{Consent for publication}

Not applicable.

\section{Competing interests}

The authors declare that they have no competing interests.

\section{Author details}

'Departamento de Saúde Comunitária. Rua Professor Costa Mendes 1608 Bloco Didático $5^{\circ}$ andar - Rodolfo Teófilo, Universidade Federal do Ceará, Faculdade de Medicina, Fortaleza, Ceará CEP: 60430-140, Brazil. ${ }^{2}$ Secretaria da Saúde do Estado do Ceará, Fortaleza, CE, Brazil. ${ }^{3}$ Grupo de Pesquisa em Triatomíneos e Epidemiologia da Doença de Chagas, Instituto René Rachou / FIOCRUZ - MG, Belo Horizonte, MG, Brazil. ${ }^{4}$ Universidade Federal de Minas Gerais, Belo Horizonte, MG, Brazil. ${ }^{5}$ Laboratory of Eco-Epidemiology, Universidad de Buenos Aires. Facultad de Ciencias Exactas y Naturales, Ciudad Universitaria, C1428EHA Buenos Aires, Argentina. ${ }^{6}$ Instituto de Ecología, Genética y Evolución de Buenos Aires (IEGEBA). Consejo Nacional de Investigaciones Científicas y Técnicas-Universidad de Buenos Aires, Ciudad Universitaria, C1428EHA Buenos Aires, Argentina. 


\section{Received: 26 March 2020 Accepted: 17 August 2020}

\section{Published online: 27 August 2020}

\section{References}

1. Chagas C. Nova tripanossomíase humana. Mem Inst Oswaldo Cruz. 1909;1: 159-218. https://doi.org/10.1590/S0074-02761909000200008.

2. WHO. La enfermedad de Chagas (tripanosomiasis americana). Genebra 2018 (cited 2018 07/11/2018).

3. Schmunis GA, Yadon ZE. Chagas disease: a Latin American health problem becoming a world health problem. Acta Trop. 2010;115(1-2):14-21. Epub 2009/11/26. https://doi.org/10.1016/j.actatropica.2009.11.003.

4. Dias JCP, Ramos AN Jr, Gontijo ED, Luquetti A, Shikanai-Yasuda MA, Coura JR, et al. II Consenso Brasileiro em Doença de Chagas, 2015. Epidemiol Serv Saude. 2016;25:7-86. https://doi.org/10.5123/S1679-49742016000500002.

5. Martins-Melo FR, Carneiro M, Ramos AN Jr, Heukelbach J, Ribeiro ALP, Werneck GL. The burden of neglected tropical diseases in Brazil, 1990-2016: a subnational analysis from the global burden of disease study 2016. PLoS Negl Trop Dis. 2018;12(6):e0006559. Epub 2018/06/05. https://doi.org/10. 1371/journal.pntd.0006559.

6. Justi SA, Galvao C. The evolutionary origin of diversity in Chagas disease vectors. Trends Parasitol. 2017;33(1):42-52. Epub 2016/12/18. https://doi.org/ 10.1016/j.pt.2016.11.002.

7. Galvão C. Vetores da doença de chagas no Brasil: SciELO-Sociedade Brasileira de Zoologia; 2014. http://book.scielo.org/id/mw58j.

8. Schofield CJ, Galvão C. Classification, evolution, and species groups within the Triatominae. Acta Trop. 2009;110(2-3):88-100. Epub 2009/04/23. https:// doi.org/10.1016/j.actatropica.2009.01.010.

9. Costa J, Correia NC, Neiva VL, Goncalves TC, Felix M. Revalidation and redescription of Triatoma brasiliensis macromelasoma Galvao, 1956 and an identification key for the Triatoma brasiliensis complex (Hemiptera: Reduviidae: Triatominae). Mem Inst Oswaldo Cruz. 2013;108(6):785-9. Epub 2013/09/17. https://doi.org/10.1590/0074-0276108062013016.

10. Mendonça VJ, Alevi KC, Pinotti H, Gurgel-Goncalves R, Pita S, Guerra AL, et al. Revalidation of Triatoma bahiensis Sherlock \& Serafim, 1967 (Hemiptera: Reduviidae) and phylogeny of the T. brasiliensis species complex. Zootaxa. 2016;4107(2):239-54. Epub 2016/07/11. https://doi.org/10. 11646/zootaxa.4107.2.6

11. Mendonça VJ, da Silva MT, de Araujo RF, Junior JM, Junior MB, Almeida CE, et al. Phylogeny of Triatoma sherlocki (Hemiptera: Reduviidae: Triatominae) inferred from two mitochondrial genes suggests its location within the Triatoma brasiliensis complex. Am J Trop Med Hyg. 2009:81(5):858-64. Epub 2009/10/29. https://doi.org/10.4269/ajtmh.2009.08-0664.

12. Oliveira J, Marcet PL, Takiya DM, Mendonça VJ, Belintani T, Bargues MD, et al. Combined phylogenetic and morphometric information to delimit and unify the Triatoma brasiliensis species complex and the Brasiliensis subcomplex. Acta Trop. 2017;170(Supplement C):140-8. https://doi.org/10. 1016/j.actatropica.2017.02.020.

13. Forattini OP, Barata JM, Santos JL, Silveira AC. Feeding habits, natura infection and distribution of domiciliary Triatominae in the northeast region of Brazil. Rev Saúde Públ. 1981;15(2):113-64. Epub 1981/04/01. https://doi. org/10.1590/S0034-89101981000200002.

14. Costa J, Almeida CE, Dotson EM, Lins A, Vinhaes M, Silveira AC, et al. The epidemiologic importance of Triatoma brasiliensis as a chagas disease vector in Brazil: a revision of domiciliary captures during 1993-1999. Mem Inst Oswaldo Cruz. 2003;98(4):443-9. Epub 2003/08/26. https://doi.org/10. 1590/S0074-02762003000400002

15. Dias JCP, Machado EMM, Fernandes AL, Vinhaes MC. Esboço geral e perspectivas da doença de Chagas no Nordeste do Brasil. Cad Saude Publica. 2000;16(Sup. 2):13-24. https://doi.org/10.1590/S0102$311 \times 2000000800003$.

16. Lilioso M, Folly-Ramos E, Rocha FL, Rabinovich J, Capdevielle-Dulac C, Harry $M$, et al. High Triatoma brasiliensis densities and Trypanosoma cruzi prevalence in domestic and peridomestic habitats in the state of Rio Grande do Norte, Brazil: the source for Chagas disease outbreaks? Am J Trop Med Hyg. 2017;96(6):1456-9. Epub 2017/07/19. https://doi.org/10.4269/ ajtmh.16-0823.

17. Sarquis O, Sposina R, de Oliveira TG, Mac Cord JR, Cabello PH, BorgesPereira J, et al. Aspects of peridomiciliary ecotopes in rural areas of northeastern Brazil associated to triatomine (Hemiptera, Reduviidae) infestation, vectors of chagas disease. Mem Inst Oswaldo Cruz. 2006;101(2): 143-7. Epub 2006/07/13. https://doi.org/10.1590/S0074-02762006000200005.
18. Bezerra CM, Cavalcanti LP, Souza Rde C, Barbosa SE, Xavier SC, Jansen AM, et al. Domestic, peridomestic and wild hosts in the transmission of Trypanosoma cruzi in the Caatinga area colonised by Triatoma brasiliensis. Mem Inst Oswaldo Cruz. 2014;109(7):887-98. Epub 2014/11/21. https://doi. org/10.1590/0074-0276140048.

19. Borges EC, Dujardin JP, Schofield CJ, Romanha AJ, Diotaiuti L. Dynamics between sylvatic, peridomestic and domestic populations of Triatoma brasiliensis (Hemiptera: Reduviidae) in Ceara state, Northeastern Brazil. Acta Trop. 2005;93(1):119-26. Epub 2004/12/14. https://doi.org/10.1016/j. actatropica.2004.10.002.

20. Carcavallo RU, Giron IG, Jurberg J, Lent H. Atlas Dos Vetores Da Doença de Chagas Nas Américas: Editora Fiocruz; 1997.

21. Catalá S, Bezerra CM, Diotaiuti L. Thermal preferences and limits of Triatoma brasiliensis in its natural environment--field observations while host searching. Mem Inst Oswaldo Cruz. 2015;110(6):793-6. Epub 2015/11/01. https://doi.org/10.1590/S0074-02760150234.

22. Schofield CJ, Diotaiuti L, Dujardin JP. The process of domestication in Triatominae. Mem Inst Oswaldo Cruz. 1999;94(Suppl 1):375-8. Epub 2000/ 06/10. https://doi.org/10.1590/S0074-02761999000700073.

23. Almeida CE, Faucher L, Lavina M, Costa J, Harry M. Molecular individualbased approach on Triatoma brasiliensis: inferences on Triatomine foci, Trypanosoma cruzi natural infection prevalence, parasite diversity and feeding sources. PLoS Negl Trop Dis. 2016;10(2):e0004447. Epub 2016/02/20. https://doi.org/10.1371/journal.pntd.0004447.

24. Oliveira MT, Branquinho RT, Alessio GD, Mello CG, Nogueira-de-Paiva NC, Carneiro CM, et al. Tcl, Tcll and TcVl Trypanosoma cruzi samples from Chagas disease patients with distinct clinical forms and critical analysis of in vitro and in vivo behavior, response to treatment and infection evolution in murine model. Acta Trop. 2017;167:108-20. Epub 2016/12/03. https://doi. org/10.1016/j.actatropica.2016.11.033.

25. Almeida CE, Pacheco RS, Haag K, Dupas S, Dotson EM, Costa J. Inferring from the Cyt B gene the Triatoma brasiliensis Neiva, 1911 (Hemiptera: Reduviidae: Triatominae) genetic structure and domiciliary infestation in the state of Paraiba, Brazil. Am J Trop Med Hyg. 2008;78(5):791-802 Epub 2008/05/07.

26. Borges EC, Romanha AJ, Diotaiuti L. Use of random amplified polymorphic DNA (RAPD) in the populational study of Triatoma brasiliensis Neiva, 1911. Cad Saude Publica. 2000;16(Suppl 2):97-100. Epub 2000/12/19. https://doi. org/10.1590/S0102-311X2000000800012.

27. Costa J, Freitas-Sibajev MG, Marchon-Silva V, Pires MQ, Pacheco RS. Isoenzymes detect variation in populations of Triatoma brasiliensis (Hemiptera: Reduviidae: Triatominae). Mem Inst Oswaldo Cruz. 1997;92(4): 459-64. Epub 1997/07/01. https://doi.org/10.1590/S007402761997000400002

28. Harry M, Dupont L, Quartier M, Diotaiuti L, Walter A, Romana C. New perspectives for population genetics of Chagas'disease vectors in the northeastern Brazil: isolation of polymorphic microsatellite markers in Triatoma brasiliensis. Infect Gene Evol. 2009;9(4):633-7. Epub 2009/05/23. https://doi.org/10.1016/j.meegid.2009.03.008.

29. Ferreira M, Grattapaglia D. Introdução ao uso de marcadores moleculares em análise genética. 3a ed. Brasília, DF: EMBRAPA Recursos Genéticos e Biotecnologia; 1998. p. 220.

30. Balloux F, Lugon-Moulin N. The estimation of population differentiation with microsatellite markersMol. Ecol. 2002;11(2):155-65. Epub 2002/02/22. https://doi.org/10.1046/j.0962-1083.2001.01436.x.

31. Martins W, de Sousa D, Proite K, Guimaraes P, Moretzsohn M, Bertioli D. New softwares for automated microsatellite marker development. Nucleic Acids Res. 2006;34(4):e31. Epub 2006/02/24. https://doi.org/10.1093/nar/gnj030.

32. Foley EA, Khatchikian CE, Hwang J, Ancca-Juarez J, Borrini-Mayori K, QuispeMachaca VR, et al. Population structure of the Chagas disease vector, Triatoma infestans, at the urban-rural interfaceMol. Ecol. 2013;22(20):5162-71. Epub 2013/10/10. https://doi.org/10.1111/mec.12471.

33. Harry $M$, Roose $C L$, Vautrin $D$, Noireau F, Romana CA, Solignac M. Microsatellite markers from the Chagas disease vector, Rhodnius prolixus (Hemiptera, Reduviidae), and their applicability to Rhodnius species. Infect Gene Evol. 2008;8(3):381-5. Epub 2008/02/29. https://doi.org/10.1016/j. meegid.2008.01.006.

34. Harry M, Dupont L, Romana C, Demanche C, Mercier A, Livet A, et al. Microsatellite markers in Triatoma pseudomaculata (Hemiptera, Reduviidae, Triatominae), Chagas' disease vector in Brazil. Infect Gene Evol. 2008;8(5): 672-5. Epub 2008/06/24. https://doi.org/10.1016/j.meegid.2008.03.005. 
35. Piccinali RV, Gaunt MW, Gurtler RE. A microsatellite-based analysis of house infestation with Triatoma Infestans (Hemiptera: Reduviidae) after insecticide spraying in the argentine Chaco. J Med Entomol. 2018;55(3):609-19. Epub 2018/02/01. https://doi.org/10.1093/jme/tjx256.

36. Garcia BA, Zheng L, Rosas ARPD, Segura EL. Isolation and characterization of polymorphic microsatellite loci in the Chagas' disease vector Triatoma infestans (Hemiptera: Reduviidae). Mol Ecol Notes. 2004;4(4):568-71. https:// doi.org/10.1111/j.1471-8286.2004.00735.x.

37. Diotaiuti L, Faria Filho OF, Carneiro FC, Dias JC, Pires HH, Schofield CJ. Operational aspects of Triatoma brasiliensis control. Cad Saude Publica. 2000;16(Suppl 2):61-7 Epub 2000/12/19.

38. Lorenzo MG, Guarneri AA, Pires HH, Diotaiuti L, Lazzari CR. Microclimatic properties of the Triatoma brasiliensis habitat. Cad Saude Publica. 2000; 16(Suppl 2):69-74 Epub 2000/12/19.

39. Rabinovich JE, Kitron UD, Obed Y, Yoshioka M, Gottdenker N, Chaves LF. Ecological patterns of blood-feeding by kissing-bugs (Hemiptera: Reduviidae: Triatominae). Mem Inst Oswaldo Cruz. 2011;106(4):479-94. Epub 2011/07/09. https://doi.org/10.1590/S0074-02762011000400016.

40. Oliveira-Lima JW, Faria Filho OF, Vieira JB, Gadelha FV, Oliveira Filho AM Peridomiciliary changes and implications for Triatoma brasiliensis control. Cad Saude Publica. 2000;16(Suppl 2):75-81 Epub 2000/12/19.

41. Harry M, Lema F, Romana CA. Chagas' disease challenge. Lancet. 2000; 355(9199):236 Epub 2000/02/16

42. Dias JC, Machado EM, Fernandes AL, Vinhaes MC. General situation and perspectives of chagas disease in northeastern region, Brazil. Cad Saude Publica. 2000;16(Suppl 2):13-34 Epub 2000/12/19.

43. Meunier I, Ferraz J. As Caatingas. Brasil: http://www.nordesterural.com.br/ dev/nordesterural/matler.asp?newsld=2359; 2005 [16/02/2008]; Available from: http://www.nordesterural.com.br/dev/nordesterural/matler. asp?newsld=2359.

44. Alencar JE. História Natural da Doença de Chagas no Estado do Ceará Fortaleza; 1987.

45. Marcet PL, Mora MS, Cutrera AP, Jones L, Gurtler RE, Kitron U, et al. Genetic structure of Triatoma infestans populations in rural communities of Santiago del Estero, northern Argentina. Infect Gene Evol. 2008;8(6):835-46. Epub 2008/09/09. https://doi.org/10.1016/j.meegid.2008.08.002.

46. Breniere SF, Salas R, Buitrago R, Bremond P, Sosa V, Bosseno MF, et al. Wild populations of Triatoma infestans are highly connected to intraperidomestic conspecific populations in the Bolivian Andes. PLoS One. 2013;8(11):e80786. Epub 2013/11/28. https://doi.org/10.1371/journal.pone. 0080786.

47. Dias FB, Paula AS, Belisario CJ, Lorenzo MG, Bezerra CM, Harry M, et al. Influence of the palm tree species on the variability of Rhodnius nasutus Stal, 1859 (Hemiptera, Reduviidae, Triatominae). Infect Genet Evol. 2011; 11(5):869-77. Epub 2011/02/22. https://doi.org/10.1016/j.meegid.2011.02.008.

48. Fitzpatrick S, Feliciangeli MD, Sanchez-Martin MJ, Monteiro FA, Miles MA. Molecular genetics reveal that silvatic Rhodnius prolixus do colonise rural houses. PLoS Negl Trop Dis. 2008;2(4):e210. Epub 2008/04/03. https://doi. org/10.1371/journal.pntd.0000210.

49. Garcia BA, de Rosas AR, Blariza MJ, Grosso CG, Fernandez CJ, Stroppa MM. Molecular population genetics and evolution of the Chagas' disease vector Triatoma infestans (Hemiptera: Reduviidae). Curr Genom. 2013;14(5):316-23. Epub 2014/01/10. https://doi.org/10.2174/13892029113149990006.

50. Perez de Rosas AR, Segura EL, Garcia BA. Microsatellite analysis of genetic structure in natural Triatoma infestans (Hemiptera: Reduviidae) populations from Argentina: its implication in assessing the effectiveness of Chagas' disease vector control programmes Mol. Ecol. 2007;16(7):1401-12. Epub 2007/03/30. https://doi.org/10.1111/j.1365-294X.2007.03251.X.

51. Perez de Rosas AR, Segura EL, Fichera L, Garcia BA. Macrogeographic and microgeographic genetic structure of the Chagas' disease vector Triatoma infestans (Hemiptera: Reduviidae) from Catamarca. Argentina Genetica. 2008; 133(3):247-60. Epub 2007/09/22. https://doi.org/10.1007/s10709-007-9208-8.

52. Pizarro JC, Gilligan LM, Stevens L. Microsatellites reveal a high population structure in Triatoma infestans from Chuquisaca, Bolivia. PLoS Negl Trop Dis. 2008;2(3):e202. Epub 2008/03/28. https://doi.org/10.1371/journal.pntd. 0000202.

53. BRASIL. Guia de Vigilância em Saúde. In: Ministério da Saúde. Secretaria de Vigilância em Saúde. Coordenação-Geral de Desenvolvimento da Epidemiologia em Serviços. Guia de Vigilância em Saúde: volume único [recurso eletrônico]. $4^{a}$ edição. Brasília: Ministério da Saúde; 2019. p. 725.
54. Leal IR, Da Silva JMC, Tabarelli M, Lacher TE. Changing the course of biodiversity conservation in the caatinga of northeastern Brazil. Biol Conserv. 2005;19:701-6. https://doi.org/10.1111/j.1523-1739.2005.00703.x.

55. Ceará. Perfil Básico Municipal de Tauá 2017: IPECE; 2017. p. 18.

56. Fernandes A. Fitogeografia Brasileira. Fortaleza: Multigraf; 2008. p. 340.

57. Oliveira EJ, Pádua JG, Zucchi MI, Vencovsky R, Carneiro LMV. Origin, evolution and genome distribution of microsatellites. Genet Mol Biol. 2006; 29(2):294-307. https://doi.org/10.1590/S1415-47572006000200018.

58. Forattini OP. Biogeography, origin and distribution of Triatominae domicile dispersal in Brazil. Rev. Saúde Públ. 1980;14(3):265-99. Epub 1980/09/01. https://doi.org/10.1590/s0034-89101980000300002.

59. BRASIL. Manual de Normas Técnicas da Campanha de Controle da Doença de Chagas; 1980. p. 167.

60. BRASIL. Orientações sobre vigilância entomológica e a utilização de inseticida de ação residual no controle de triatomíneos - vetores da doença de Chagas. Brasília: CGDT/DEVEP/SVS/MS; 2012.

61. Excoffier L, Laval G, Schneider S. Arlequin (version 3.0): An integrated software package for population genetics data analysis. Evol Bioinform Online. 2005;1:47-50 Epub 2005/01/01.

62. Excoffier L, Smouse PE, Quattro JM. Analysis of molecular variance inferred from metric distances among DNA haplotypes: application to human mitochondrial DNA restriction data. Genetics. 1992;131(2):479-91 Epub 1992/06/01

63. Raymond M, Rousset F. GENEPOP (version 1.2): population genetics software for exact tests and ecumenicism. J Hered. 1995;86(3):248-9. https:// doi.org/10.1093/oxfordjournals.jhered.a111573.

64. Rousset F. genepop'007: a complete re-implementation of the genepop software for windows and Linux. Mol Ecol. 2008;8(1):103-6. Epub 2008/01/ 01. https://doi.org/10.1111/j.1471-8286.2007.01931.x.

65. Pritchard JK, Stephens M, Donnelly P. Inference of population structure using multilocus genotype data. Genetics. 2000;155(2):945-59 Epub 2000/06/03.

66. Takezaki N, Nei M, Tamura K. POPTREEW: web version of POPTREE for constructing population trees from allele frequency data and computing some other quantities. Mol Biol Evol. 2014;31(6):1622-4. Epub 2014/03/08. https://doi.org/10.1093/molbev/msu093.

\section{Publisher's Note}

Springer Nature remains neutral with regard to jurisdictional claims in published maps and institutional affiliations.

Ready to submit your research? Choose BMC and benefit from:

- fast, convenient online submission

- thorough peer review by experienced researchers in your field

- rapid publication on acceptance

- support for research data, including large and complex data types

- gold Open Access which fosters wider collaboration and increased citations

- maximum visibility for your research: over $100 \mathrm{M}$ website views per year

At BMC, research is always in progress.

Learn more biomedcentral.com/submissions 